Check for updates

Cite this: Chem. Commun., 2017, 53, 10808

Received 26th July 2017,

Accepted 12th September 2017

DOI: $10.1039 / \mathrm{c7cc05818g}$

rsc.li/chemcomm

\section{Oxygenation of RZn(N,O)-type complexes as an efficient route to zinc alkoxides not accessible via the classical alcoholysis path $\dagger$}

\author{
Zbigniew Wróbel, ${ }^{a}$ Tomasz Pietrzak, ${ }^{b}$ Iwona Justyniak ${ }^{\mathrm{a}}$ and Janusz Lewiński (DD *ab
}

The controlled oxygenation of alkylzinc complexes supported by a 2-ester substituted pyrrolate ligand (L) leads to zinc alkoxides with an uncommon structural motif in the solid state: a trimer $\left[(\mathrm{L}) \mathrm{Zn}\left(\mu-\mathrm{O}^{t} \mathrm{Bu}\right)\right]_{3}$ with the central $\left[\mathrm{Zn}_{3}(\mu-\mathrm{OR})_{3}\right]$ ring and a tetramer $\left[(\mathrm{L}) \mathrm{Zn}\left(\mu_{3}-\mathrm{OEt}\right)\right]_{4}$ with a heterocubane-type structure. Strikingly, these seemingly simple zinc alkoxides are not accessible via the classical alcoholysis route.

Simple alkylzinc alkoxides as well as alkoxide zinc complexes supported by a variety of organic chelating ligands have been well known for their rich structural diversity and practical applications in polymerization chemistry and materials science. For example, easily accessible $\left[\mathrm{RZn}\left(\mu_{3}-\mathrm{OR}^{\prime}\right)\right]_{4}$-type alkoxides with heterocubane architecture have been extensively studied as predesigned single source precursors of $\mathrm{ZnO}$ nanocrystals. ${ }^{1}$ In turn, zinc alkoxides incorporating various monoanionic multidentate ligands have been widely used as effective initiators in the ringopening polymerization of heterocyclic monomers ${ }^{2}$ and copolymerization of epoxides and $\mathrm{CO}_{2}{ }^{3}$ These initiators have commonly been generated in situ in equimolar reactions between $\mathrm{RZn}(\mathrm{X}, \mathrm{Y})$ type complexes and an alcohol. However, some data demonstrate that in fact the outcomes, in these alcoholysis reactions, are not always obvious, mostly due to the inability to isolate and structurally characterize the resulting products. ${ }^{4}$ Interestingly, despite the fact that zinc alkoxides can also be synthesized by the controlled oxygenation of zinc alkyl precursors, this method has not hitherto gained considerable attention. In this report, we demonstrate that zinc alkoxides of the type $[(\mathrm{L}) \mathrm{Zn}(\mu-\mathrm{OR})]$ (where $\mathrm{L}=\mathrm{O}$,N-bidentate ligand) might be successfully obtained by the controlled oxygenation of the respective alkylzinc complexes, whilst they are not accessible via the alcoholysis reaction. To the best of our

\footnotetext{
${ }^{a}$ Institute of Physical Chemistry, Polish Academy of Sciences, Kasprzaka 44/52, Warsaw 01-224, Poland

${ }^{b}$ Department of Chemistry, Warsaw University of Technology, Noakowskiego 3, Warsaw 00-664, Poland. E-mail: lewin@ch.pw.edu.pl

$\dagger$ Electronic supplementary information (ESI) available: All experimental details and characterization data. CCDC 1555507-1555509. For ESI and crystallographic data in CIF or other electronic format see DOI: 10.1039/c7cc05818g
}

knowledge, this is the first report which unambiguously proved the superiority of the oxygenation approach over the classical alcoholysis route.

Others $^{5}$ and our group ${ }^{6}$ have reported that the controlled oxygenation of alkylzinc complexes incorporating $\mathrm{O}, \mathrm{O}^{\prime}$-bidentate ligands or O,N-ligands with an unsaturated backbone led to zinc alkoxides (Scheme 1A, path A) or zinc alkylperoxides (Scheme 1A, path B), respectively, which feature tetranuclear structures with a $\mathrm{Zn}_{4} \mathrm{O}_{6}$ double-open face-shared dicubane core. In these cases, the resulting zinc alkoxides or alkylperoxides form stable adducts with the parent organozinc reagents and only half of the total number of the parent molecules were oxygenated, whilst the rest remained intact in spite of the excess of $\mathrm{O}_{2}$ (Scheme 1A). In turn, the oxygenation of alkylzinc complexes supported by a pyrrole-based $\mathrm{N}, \mathrm{N}^{\prime}$-ligand provided a new zinc alkylperoxide or a tetranuclear zinc oxo-encapsulated cluster, and the formation of significantly different post-oxygenation products was determined by the characteristic of the alkyl substituent of the parent zinc complex. ${ }^{7}$ With regard to our systematic studies on the oxygenation of zinc alkyls, ${ }^{6-8}$ herein we describe the synthesis and

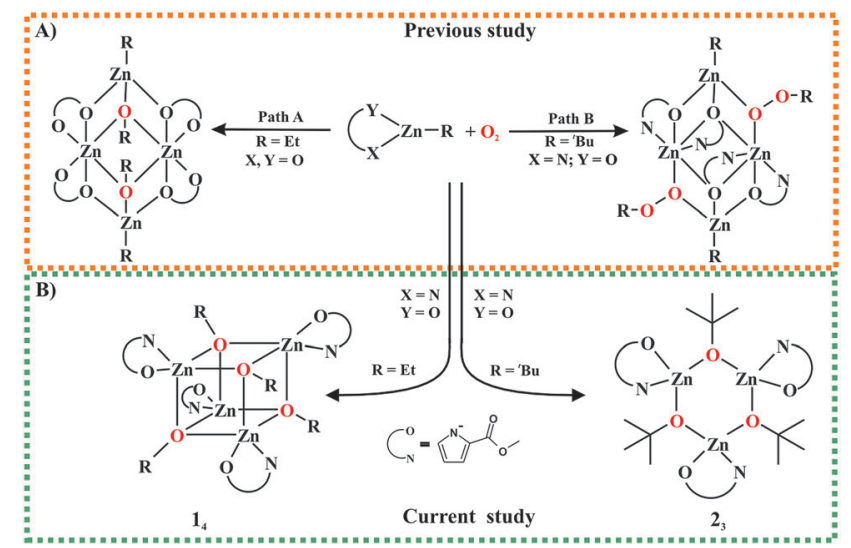

Scheme 1 Representation of divergent solid-state product formation by the controlled oxygenation of alkylzinc complexes incorporating monoanionic $X, Y$-bidentate ligands. 
structure characterization of zinc alkoxides supported by a bidentate $\mathrm{N}, \mathrm{O}$-ligand possessing unprecedented trimeric and tetrameric structural motifs in the solid state (Scheme 1B). The well-defined zinc alkoxides were derived from the controlled oxygenation of RZn(N,O)-type complexes incorporating a 2-ester substituted pyrrolate ligand, and their structures in the solid state and solution were strongly determined by the nature of the zinc bonded alkoxide substituent. Remarkably, attempts to prepare these alkoxide complexes via the classical alcoholysis reaction failed.

The starting alkylzinc pyrrolate-ester complexes were readily prepared by the equimolar reaction between $\mathrm{R}_{2} \mathrm{Zn}$ (where $\mathrm{R}=\mathrm{Et}$ or ${ }^{t} \mathrm{Bu}$ ) and methyl-1H-pyrrole-2-carboxylate $(\mathrm{L}-\mathrm{H})$ according to the previously reported procedure. ${ }^{9}$ Next, the treatment of toluene solutions of the respective $[\mathrm{RZn}(\mathrm{L})]$ complexes with dry $\mathrm{O}_{2}$ at $-20{ }^{\circ} \mathrm{C}$ for ca. 2 hours followed by concentration of the reaction mixtures and crystallization at $20{ }^{\circ} \mathrm{C}$ led selectively to the formation of zinc alkoxides [EtOZn(L)] (1) or $\left[{ }^{t} \mathrm{BuOZn}(\mathrm{L})\right]$ (2) in high yields (Scheme 1B). The ${ }^{1} \mathrm{H}$ NMR spectra of the postreaction solid residues contain only the pattern characteristic of the pyrrolate ligand and the signal attributed to the $\mathrm{Zn}-\mathrm{OR}$ protons. The latter observation clearly indicates that all of the parent $\mathrm{Zn}-\mathrm{R}$ units were oxygenated. Compounds $\mathbf{1}$ and $\mathbf{2}$ were characterized spectroscopically, including by diffusion-ordered (DOSY) ${ }^{1} \mathrm{H}$ NMR spectroscopy, ${ }^{10}$ and their identity in the solid state was determined by single crystal X-ray diffraction studies.

The ${ }^{1} \mathrm{H}$ NMR spectra of 1 in toluene- $d_{8}$ collected in the range of $-70{ }^{\circ} \mathrm{C}$ to $70{ }^{\circ} \mathrm{C}$ show a single set of signals corresponding to the pyrrole ligand and the $\mathrm{Zn}$-OEt group. The DOSY ${ }^{1} \mathrm{H}$ NMR study at $30{ }^{\circ} \mathrm{C}$ indicates that the zinc ethoxide complex exists as a tetramer $\mathbf{1}_{\mathbf{4}}$ in toluene (for details, see the ESI $\dagger$ ) like classical $\left[\mathrm{RZn}\left(\mu_{3}-\mathrm{OR}^{\prime}\right)\right]_{4}$-type heterocubanes. ${ }^{11}$ Compound 1 crystallizes in the space group $P 2_{1} / c$ as a tetramer $\mathbf{1}_{4}$ with a slightly distorted $\mathrm{Zn}_{4} \mathrm{O}_{4}$ heterocubane structure (Fig. 1). The fivecoordinate metal centers are bridged by ethoxide groups with the $\mu_{3}$-binding mode, and their coordination spheres are fulfilled by the chelating pyrrole-based ligand. The $\mathrm{Zn}-\mathrm{O}$ bond distances in $\mathbf{1}_{\mathbf{4}}$ fall in the range of 2.006-2.167 $\AA$ and are close to those found for $\left[\mathrm{RZn}\left(\mu_{3}-\mathrm{OR}^{\prime}\right)\right]_{4}$-type heterocubanes (for the selected geometric parameters, see the ESI $\dagger$ ). ${ }^{11,12}$ To the best of our knowledge, $\mathbf{1}_{\mathbf{4}}$ is the first example of zinc alkoxide with a discrete $\left[(\mathrm{L}) \mathrm{Zn}\left(\mu_{3}-\mathrm{OR}^{\prime}\right)\right]_{4}{ }^{-}$ type cubane-like architecture supported by a chelating ligand. The accompanying analysis of the Cambridge Structural Database (version 1.19) shows that such a structural motif has seldom been observed and reported only for $\mathrm{Cu}(\mathrm{II})$ and $\mathrm{Co}(\mathrm{II})$ alkoxides incorporating $\beta$-diketonate ligands. ${ }^{13}$

Remarkably, the replacement of the ethoxide group by the tert-butoxide in 2 dramatically changes its solution and solid state structures. The ${ }^{1} \mathrm{H}$ NMR spectrum of 2 at $-70{ }^{\circ} \mathrm{C}$ shows a triple set of signals corresponding to the pyrrole ligand and $\mathrm{ZnO}^{t} \mathrm{Bu}$ group (Fig. 2). With an increase in temperature up to $70{ }^{\circ} \mathrm{C}$ the signals do not coalesce, but their relative intensities significantly change. These observations suggest the presence of three forms of 2 in a toluene solution. Indeed, the DOSY NMR studies at $30{ }^{\circ} \mathrm{C}$ show that 2 exists in a monomer-dimer equilibrium (for details, see the ESI $\dagger$ ). The double set of signals

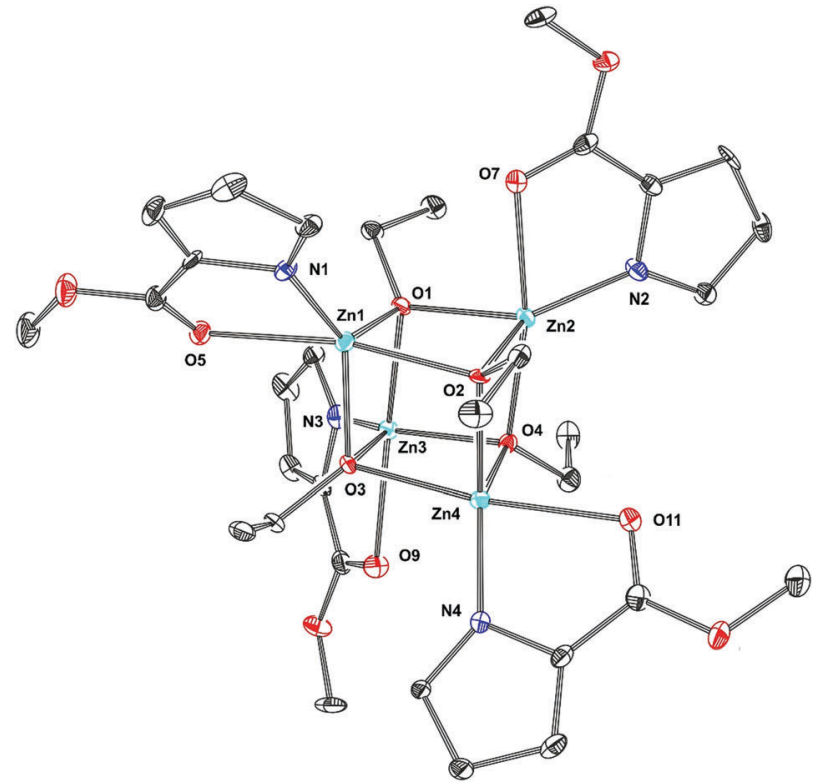

Fig. 1 The molecular structure of $\mathbf{1}_{\mathbf{4}}$. Hydrogen atoms are omitted for clarity.

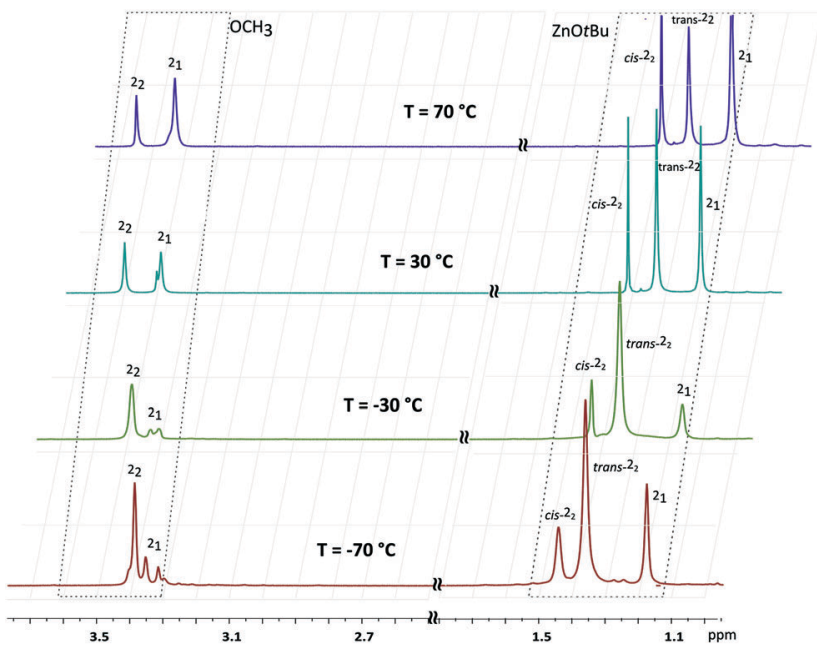

Fig. 2 Variable-temperature ${ }^{1} \mathrm{H}$ NMR spectra of compound $\mathbf{2}$ in toluene- $d_{8}$.

corresponding to dimeric species indicates the presence of two geometric isomers of $2_{2}$, i.e., cis-2 $\mathbf{2}_{2}$ and trans-2, as shown in Scheme 2. A detailed analysis of the variable-temperature ${ }^{1} \mathrm{H}$ NMR spectra also indicates the domination of one dimeric form of 2 , likely a trans isomer. Interestingly, all three structural forms are still observed at $70{ }^{\circ} \mathrm{C}$. The presence of well-separated resonances even at $70{ }^{\circ} \mathrm{C}$ indicates that exchange processes between various forms of 2 are relatively slow in the NMR scale. Compound $2_{3}$ crystallizes in the space group $P \overline{1}$ as a trimer with the three discrete monomeric $\left[{ }^{t} \mathrm{BuOZn}(\mathrm{L})\right]$ units bridged by the tert-butoxide groups with the $\mu$-O bridging mode (Fig. 3). The $\mathrm{Zn}-\mathrm{O}$ bond distances in $23_{3}$ fall within the range of 1.9159-1.9447 $\AA$. The average $\mathrm{Zn}-\mathrm{O}_{\text {carbonyl }}$ and $\mathrm{Zn}-\mathrm{N}_{\text {pyrrole }}$ bond lengths are 2.278-2.319 $\mathrm{\AA}$ for $\mathbf{1}_{4}$ and 2.104-2.112 $\AA$ for $2_{3}$, and 1.921-1.942 $\AA$ for $\mathbf{1}_{4}$ and 


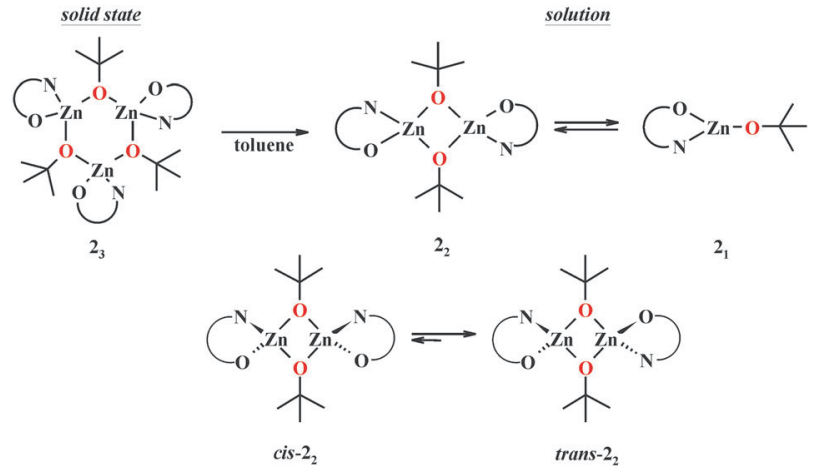

Scheme 2 Representation of various structural forms of 2 upon dissolution of $\mathbf{2}_{3}$ in toluene.

1.961-1.978 $\AA$ for $2_{3}$, respectively (for the selected geometric parameters, see ESI $\dagger)$. The resulting cyclic central $\left[\mathrm{Zn}_{3}(\mu-\mathrm{OR})_{3}\right]$ ring in $2_{3}$ nicely resembles the hitherto elusive structural motif commonly considered for trimeric $\left[\mathrm{RZnOR}^{\prime}\right]_{3}$-type zinc alkoxides. ${ }^{14}$ Remarkably, the Cambridge Structural Database search revealed that such a trimeric structure has been reported neither for zinc nor for other divalent metal complexes. Thus, the data indicate that in the case of 2 the introduction of the sterically hindered tert-butoxide group effectively hinders the formation of the most thermodynamically favorable tetrameric heterocubane structure for zinc alkoxides. As a consequence, an uncommon trimeric structure is formed in the solid state, which readily dissociates to equilibrating dimeric and monomeric species in solution.

As mentioned in the introduction, zinc alkoxides with a variety of stabilizing ligands, used as initiators of heterocyclic polymers, have been commonly generated by the alcoholysis of the corresponding zinc alkyls complexes. Thus, in the next step

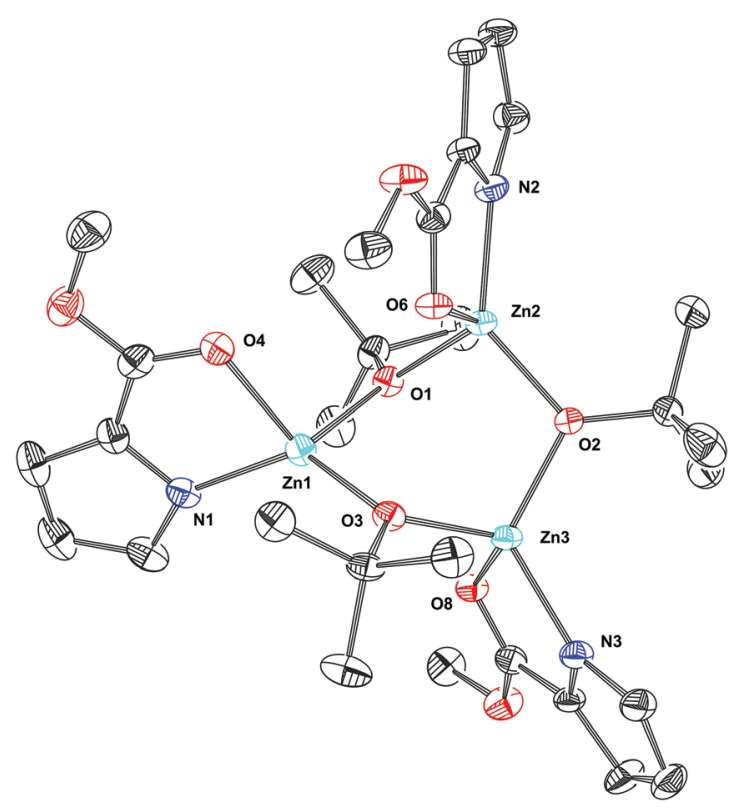

Fig. 3 The molecular structure of $\mathbf{2}_{\mathbf{3}}$. Hydrogen atoms are omitted for clarity.

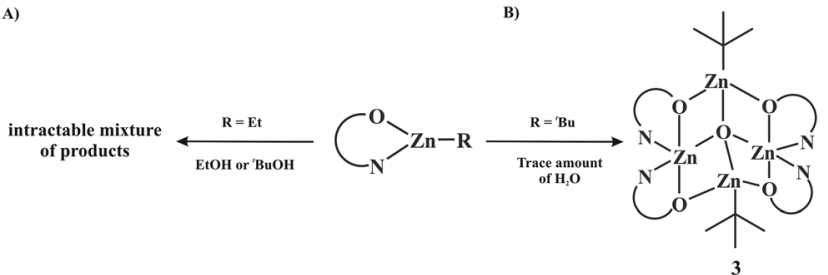

Scheme 3 Probing the reactivity of $[R Z n(L)]$ complexes towards (a) intentionally added alcohols and (b) traces of water.

we endeavoured to explore the reactivity of the ethylzinc complex incorporating the 2-ester substituted pyrrolate ligand, $\operatorname{EtZn}(\mathrm{L})$, towards a stoichiometric amount of alcohols in order to obtain anticipated compounds $\mathbf{1}_{4}$ and $\mathbf{2}_{3}$. In control experiments, an equimolar amount of dry $\mathrm{EtOH}$ or $t \mathrm{BuOH}$ was added dropwise to a toluene solution of $[\operatorname{EtZn}(\mathrm{L})]$ at $-78{ }^{\circ} \mathrm{C}$. Next, the resulting reaction mixtures were warmed up to ambient temperature and stirred for ca. 24 h. Remarkably, despite several attempts being made under various conditions, neither the reaction with EtOH nor the reaction with $t \mathrm{BuOH}$ leads to the well-defined products (Scheme 3A). Moreover, the analysis of the ${ }^{1} \mathrm{H}$ NMR spectra of the post-reaction solid residues indicates that an intractable mixture of products is formed in both cases (for details, see the ESI $\dagger$ ). Thus, the data not only highlight a pronounced difference between the reaction outcomes in the oxygenation and alcoholysis of the studied alkylzinc complexes, but also provide strong evidence that the selective transformation of alkyl zinc complexes of RZn(L)-type to the corresponding zinc alkoxide species is a non-trivial issue and undoubtedly deserves more in-depth investigations.

In the course of our investigations, we also obtained an alkylzinc oxo cluster, $\left[\left({ }^{t} \mathrm{Bu}\right)_{2} \mathrm{Zn}_{4}\left(\mu_{4}-\mathrm{O}\right)(\mathrm{L}) 3_{4}\right]$ (3) (Scheme 3B). This compound was isolated with low yield as colorless cubiclike crystals from a toluene/hexane solution of as-prepared $\left[\left({ }^{t} \mathrm{Bu}\right) \mathrm{Zn}(\mathrm{L})\right]_{n}$ at $-20{ }^{\circ} \mathrm{C}$. The source of the oxygen contamination remains an open question; however, it is very likely that the formation of the oxo anion is due to the presence of water traces in the reaction mixture. ${ }^{15}$ Compound 3 was characterized spectroscopically and by single crystal X-ray diffraction studies (for details, see the ESI $\dagger$ ). Compound 3 crystallizes in the space group $C 2 / c$ as a tetranuclear cluster with an encapsulation described as a zincoxane $\left(t \mathrm{Bu}_{2} \mathrm{Zn}_{2} \mathrm{O}\right)$ moiety entrapped by two $\mu_{4}-\mathrm{O}^{2-}$ oxo ions (Fig. 4). Formally, its composition may also be bischelate $\left[\mathrm{Zn}(\mathrm{L})_{2}\right]$ units; similar zincoxane-entrapment products have previously been observed in the reaction systems involving alkylzinc complexes incorporating bicyclic guanidinate, carbamate or diorganophosphate ligands. ${ }^{16}$ The central core of 3 contains the four-coordinate oxygen atom possessing a near tetrahedral geometry, while the $\mathrm{Zn}_{4}\left(\mu_{4}-\mathrm{O}\right)$ bond distances fall in a narrow range of 1.935-1.973 $\AA$ (for the selected geometric parameters, see the $\mathrm{ESI} \dagger$ ).

In conclusion, the synthesis of zinc alkoxides of the type $[(\mathrm{L}) \mathrm{Zn}(\mu-\mathrm{OR})]$ was successfully achieved by the controlled oxygenation of alkylzinc complexes incorporating the pyrrolate N,O-ligand. Their structures in solution and the solid state 


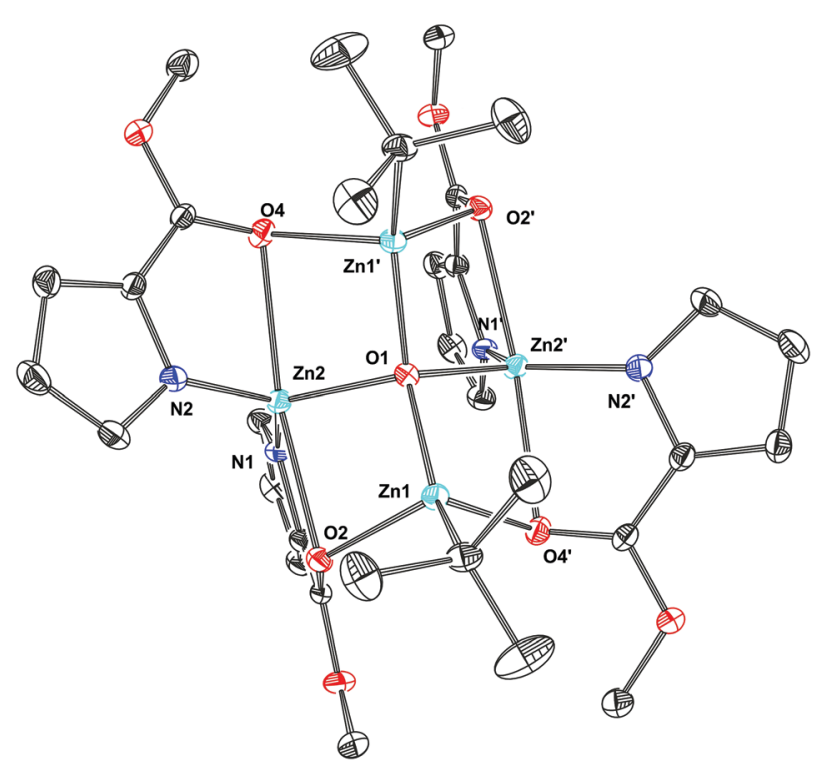

Fig. 4 The molecular structure of 3 . Hydrogen atoms are omitted for clarity.

significantly vary and are strongly determined by the nature of zinc bonded alkoxide substituent. Strikingly, the accompanying studies demonstrated that these alkoxides are not accessible via classical alcoholysis reactions. In our opinion, these intriguing findings will stimulate further systematic studies on both the oxygenation and alcoholysis chemistry of organozincs as a tool for the preparation of desired zinc alkoxides.

The authors would like to acknowledge the National Science Centre, Grant Maestro DEC-2012/04/A/ST5/00595, for financial support.

\section{Conflicts of interest}

There are no conflicts to declare.

\section{Notes and references}

1 For selected examples, see: (a) V. Ischenko, S. Polarz, D. Grote, V. Stavarache, K. Fink and M. Driess, Adv. Funct. Mater., 2005, 15, 1945; (b) S. Polarz, J. Strunk, V. Ischenko, M. W. E. van den Berg, O. Hinrichsen, M. Muhler and M. Driess, Angew. Chem., Int. Ed., 2006, 45, 2965; (c) S. Polarz, R. Regenspurger and J. Hartmann, Angew. Chem., Int. Ed., 2007, 46, 2426; (d) K. Sokołowski, I. Justyniak, W. Bury, J. Grzonka, Z. Kaszkur, Ł. Mąkolski, M. Dutkiewicz, A. Lewalska, D. Kubicki, K. Wójcik, K. Kurzydłowski and J. Lewiński, Chem. - Eur. J., 2015, 21, 5488.

2 (a) R. H. Platel, L. M. Hodgson and C. K. Williams, Polym. Rev., 2008, 48, 11; (b) S. Klaus, M. W. Lehenmeier, C. E. Anderson and B. Rieger, Coord. Chem. Rev., 2011, 255, 1460.

3 (a) D. J. Darensbourg, Chem. Rev., 2007, 107, 2388; (b) M. R. Kember, A. Buchard and C. K. Williams, Chem. Commun., 2011, 47, 141.

4 For selected examples, see: $(a)$ K. Nakano, K. Nozaki and T. Hiyama, J. Am. Chem. Soc., 2003, 125, 5501; (b) J. D. Farwell, P. B. Hitchcock, M. F. Lappert, G. A. Luinstra, A. V. Protchenko and X.-H. Wei, J. Organomet. Chem., 2008, 693, 1861; (c) E. Grunova, T. Roisnel and J.-F. Carpentier, Dalton Trans., 2009, 9010; (d) G. Labourdette, D. J. Lee, B. O. Patrick, M. B. Ezhova and P. Mehrkhodavandi, Organometallics, 2009, 28, 1309; (e) C. Bakewell, G. Fateh-Iravani, D. W. Beh, D. Myers, S. Tabthong, P. Hormnirun, A. J. P. White, N. Long and C. K. Williams, Dalton Trans., 2015, 44, 12326; $(f)$ D. Jędrzkiewicz, G. Adamus, M. Kwiecień, Ł. John and J. Ejfler, Inorg. Chem., 2017, 56, 1349; $(g)$ M. Leszczyński, I. Justyniak, K. Zelga and J. Lewiński, Dalton Trans., 2017, DOI: 10.1039/c7dt01619k; (h) M. T. Chen and C. T. Chen, Dalton Trans., 2017, 46, 10181.

5 (a) R. Petrus and P. Sobota, Organometallics, 2012, 31, 4755; (b) J. A. Manzi, C. E. Knapp, I. P. Parkin and C. J. Carmalt, ChemistryOpen, 2016, 5, 301.

6 J. Lewiński, W. Marciniak, J. Lipkowski and I. Justyniak, J. Am. Chem. Soc., 2003, 125, 12698.

7 J. Lewiński, K. Suwała, T. Kaczorowski, M. Gałęzowski, D. T. Gryko, I. Justyniak and J. Lipkowski, Chem. Commun., 2009, 215.

8 For selected examples, see: (a) J. Lewiński, W. Śliwiński, M. Dranka, I. Justyniak and J. Lipkowski, Angew. Chem., Int. Ed., 2006, 45, 4826; (b) J. Lewiński, K. Suwała, M. Kubisiak, Z. Ochal, I. Justyniak and J. Lipkowski, Angew. Chem., Int. Ed., 2008, 47, 7888; (c) J. Lewiński, M. Kościelski, K. Suwała and I. Justyniak, Angew. Chem., Int. Ed., 2009, 48, 7017; (d) Ł. Makolski, K. Zelga, R. Petrus, D. Kubicki, P. Zarzycki, P. Sobota and J. Lewiński, Chem. - Eur. J., 2014, 20, 14790; (e) M. Kubisiak, K. Zelga, W. Bury, I. Justyniak, K. Budny-Godlewski, Z. Ochal and J. Lewiński, Chem. Sci., 2015, 6, 3102; $(f)$ T. Pietrzak, M. D. Korzyński, I. Justyniak, K. Zelga, A. Kornowicz, Z. Ochal and J. Lewiński, Chem. - Eur. J., 2017, 27, 7997; (g) M. K. Leszczyński, I. Justyniak and J. Lewiński, Organometallics, 2017, 36, 2377.

9 (a) J. Lewiński, M. Dranka, I. Kraszewska, W. Śliwiński and I. Justyniak, Chem. Commun., 2005, 4935; (b) Z. Wróbel, I. Justyniak, I. Dranka and J. Lewiński, Dalton Trans., 2016, 45, 7240.

10 DOSY ${ }^{1} \mathrm{H}$ NMR spectroscopy has been successfully applied for the characterization of various organozinc systems in solution, for examples see: (a) D. R. Armstrong, W. Clegg, P. Garcia-Alvarez, M. D. McCall, L. Nuttall, A. R. Kennedy, L. Russo and E. Hevia, Chem. - Eur. J., 2011, 17, 4470; (b) I. Dranka, M. Kubisiak, I. Justyniak, M. Lesiuk, D. Kubicki and J. Lewiński, Chem. - Eur. J., 2011, 17, 12713; (c) A. Hernan-Gomez, E. Herd, E. Hevia, A. R. Kennedy, P. Knochel, K. Koszinowski, S. M. Manolikakes, R. E. Mulvey and Ch. Schnegelsberg, Angew. Chem., Int. Ed., 2014, 53, 2706; (d) K. Sokołowski, W. Bury, A. Tulewicz, A. M. Cieślak, I. Justyniak, D. Kubicki, E. Krajewska, A. Milet, R. Moszyński and J. Lewiński, Chem. - Eur. J., 2015, 21, 5496.

11 K. Sokołowski, I. Justyniak, W. Bury, J. Grzonka, Z. Kaszkur, Ł. Mąkolski, M. Dutkiewicz, A. Lewalska, D. Kubicki, K. Wójcik, K. Kurzydłowski and J. Lewiński, Chem. - Eur. J., 2015, 21, 5488.

12 S. Jana, R. J. F. Berger, R. Fröhlich, T. Pape and N. W. Mitzel, Inorg. Chem., 2007, 46, 4293.

13 (a) B. Jeżowska-Trzebiatowska, Z. Olejnik and T. Lis, J. Chem. Soc., Dalton Trans., 1981, 251; (b) C. Sirio, O. Poncelet, L. G. HubertPfalzgraf, J. C. Daran and J. Vaissermann, Polyhedron, 1992, 11, 177; (c) W. Bidell, V. Shklover and H. Berke, Inorg. Chem., 1992, 31, 5561; (d) G. D. Fallon, B. Moubaraki, K. S. Murray, A. M. van den Bergen and B. O. West, Polyhedron, 1993, 12, 1989; (e) S. Wang, J.-C. Zheng, J. R. Hall and L. K. Thompson, Polyhedron, 1994, 13, 1039; $(f)$ M. J. Delarosa, K. S. Bousman, J. T. Welch and P. J. Toscano, J. Coord. Chem., 2003, 56, 1339; (g) J. Kaizer, R. Csonka, G. Speier, M. Giorgi and M. Reglier, J. Mol. Catal. A: Chem., 2005, 235, 81; (h) M. A. K. Ahmed, H. Fjellvag, A. Kjekshu and P. D. C. Dietzel, Z. Anorg. Allg. Chem., 2007, 633, 1371; (i) G. P. Guedes, S. Soriano, N. M. Comerlato, N. L. Speziali, P. M. Lahti, M. A. Novak and M. G. F. Vaz, Eur. J. Inorg. Chem., 2012, 5642.

14 (a) J. M. Bruce, B. C. Cutsforth, D. W. Farren, F. G. Hutchinson, F. M. Rabagliat and D. R. Reed, J. Chem. Soc. B, 1966, 1020; (b) G. E. Coates and P. D. Roberts, J. Chem. Soc. A, 1967, 1233; (c) M. M. Olmstead, P. P. Power and S. C. Shoner, J. Am. Chem. Soc., 1991, 113, 3379; (d) J. Lewiński, M. Dutkiewicz, M. Lesiuk, W. Śliwiński, K. Zelga, I. Justyniak and J. Lipkowski, Angew. Chem., Int. Ed., 2010, 49, 8266.

15 D. Prochowicz, K. Sokołowski and J. Lewiński, Coord. Chem. Rev., 2014, 270, 112.

16 (a) D. Domide, C. Neuhäuser, E. Kaifer, H. Wadepohl and H.-J. Himmel, Eur. J. Inorg. Chem., 2009, 2170; (b) K. Zelga, M. Leszczyński, I. Justyniak, A. Kornowicz, M. Cabaj, A. E. H. Wheatley and J. Lewiński, Dalton Trans., 2012, 41, 5934; (c) M. Wolska-Pietkiewicz, A. Świerkosz, I. Justyniak, A. Grala, K. Sokołowski and J. Lewiński, Dalton Trans., 2016, 45, 18813; (d) M. Wolska-Pietkiewicz, A. Grala, I. Justyniak, D. Hryciuk, M. Jędrzejewska, J. Grzonka, K. Kurzydłowski and J. Lewiński, Chem. Eur. J., 2017, 23, 11856. 